\title{
Recent trends in chemistry and mass budget of a high altitude lake in the southern Alps (Laghetto Inferiore, Canton Ticino, Switzerland)
}

\author{
Alberto BARBIERI and Rosario MOSELLO ${ }^{1)}$ \\ Laboratorio Studi Ambientali, SPAA, DT-TI, Riva Paradiso, 15, 6900 Paradiso, Switzerland \\ ${ }^{1)}$ CNR Istituto Italiano di Idrobiologia, Largo Tonolli, 50-52, Verbania-Pallanza, Italy \\ *e-mail corresponding author: alberto.barbieri@ti.ch
}

\begin{abstract}
Since 1980, surveys have been performed every three years on about 50 small high-altitude Alpine lakes located in the Swiss part of the Lago Maggiore watershed (Southern Central Alps). Since 1996 one of these lakes, Laghetto Inferiore (LI) has been included in the Mountain Lakes Research (MOLAR) program, an extensive European co-operative research project with 23 partners. Laghetto Inferiore, situated at $2074 \mathrm{~m}$ a.s.l., has a watershed mainly composed of crystalline silicic rocks, a maximum depth of $33 \mathrm{~m}$ and a theoretical renewal time of 41 days. The watershed includes a second lake, Laghetto Superiore (LS), located at $2128 \mathrm{~m}$ a.s.l. The surface water $p H$ of LI is around 6.6, while alkalinity is about $30 \mu e q l^{-1}$, increasing to $90 \mu e q l^{-1}$ at the maximum depth. Calculated inputs from atmospheric deposition and the main tributary streams were compared with changes in the lake concentration, and outflow fluxes on a monthly basis. Weathering ranged between 90-130 meq $\mathrm{m}^{-2}$ of alkalinity using a mass budget approach, of which $50 \%$ was consumed by the actual $\left(\mathrm{H}^{+}\right)$and potential $\left(\mathrm{NH}_{4}^{+}\right)$atmospheric acidity. Chemical trends over the period 1985-1998 show an increase in alkalinity and a decrease in sulphate, due to a reduction in the deposition of atmospheric acidity, and a decrease in nitrate, probably because of increased lake productivity.
\end{abstract}

Key words : Alpine lakes, hydrochemistry, acidification, deposition chemistry, trends, weathering

\section{INTRODUCTION}

Over the past 20 years the Environmental Studies Laboratory (LSA) has conducted limnological studies at high altitude Alpine lakes located on the southern side of the Central Alps (Canton Ticino), (Barbieri \& Righetti 1987; Boggero et al. 1996). Many of these studies have been in collaboration with the Italian Institute of Hydrobiology of the C.N.R. (National Research Council), which works on Alpine lakes in the Ossola Valley, bordering on the Canton Ticino (Marchetto et al. 1991, 1995; Mosello et al. 1994). Studies of lake water chemistry have concentrated mainly on acidification problems, as the geological characteristics of the area result in sensitive lakes with low buffering capacities.

Since 1980 lake chemistry studies have taken the form of six surveys, carried out at approximately threeyear intervals on a group of 21 lakes, and occasionally on a larger group of 50 lakes. The results are summarised by Boggero et al. (1996). In June 1996 a detailed limnological study was begun on Laghetto Inferiore (LI) and Laghetto Superiore (LS), which are located on the southern side of the Central Alps, in the Canton Ticino, in the watershed of the River Maggia (Fig. 1). Biological studies comprised research on phyto- and zooplankton, fish fauna and littoral benthos (Barbieri et al. 1999; Simona et al. 1999 ). Data from these two lakes were included and co-ordinated in a wider European project, Mountain Lakes Research (MOLAR), which aimed to evaluate the susceptibility of remote mountain ecosystems to acid (sulphur plus nitrogen) deposition, and to measure and model their temporal responses to climate variability (Patrick et al. 1998). In the particular case of LI, an additional objective was to assess chemical trends using the results of previous studies (Boggero et al. 1996) and relating them to trends in atmospheric deposition chemistry. Atmospheric loads were also calculated, to provide a chemical budget for the lakes during the period July 1996 to July 1997.

In this paper we evaluate these chemical results, which provide the basis of a large scale comparison with other lakes studied in the MOLAR project.

\section{STUDY AREA}

The study area is located in the Maggia Valley, in the Lago Maggiore watershed, on the southern side of the Central Alps (Fig. 1). This catchment area contains two small lakes: Laghetto Inferiore (LI), situated 2074 $\mathrm{m}$ a.s.l. in Val Maggia, and Laghetto Superiore (LS), situated $2128 \mathrm{~m}$ a.s.l., the outflow of which flows into LI. The morphometric and geographic characteristics of the catchment areas and the lake basins are given in table 1 .

The basin of LI is of glacial origin and is roughly triangular in shape; it is surrounded mainly by crystalline rocks and stony detritus $(86 \%)$, and by pasture land and shrubs $(7 \%)$. There are some small areas with limno-lacustrine deposits of mud on the shore of the lake (Boggero 1996). 


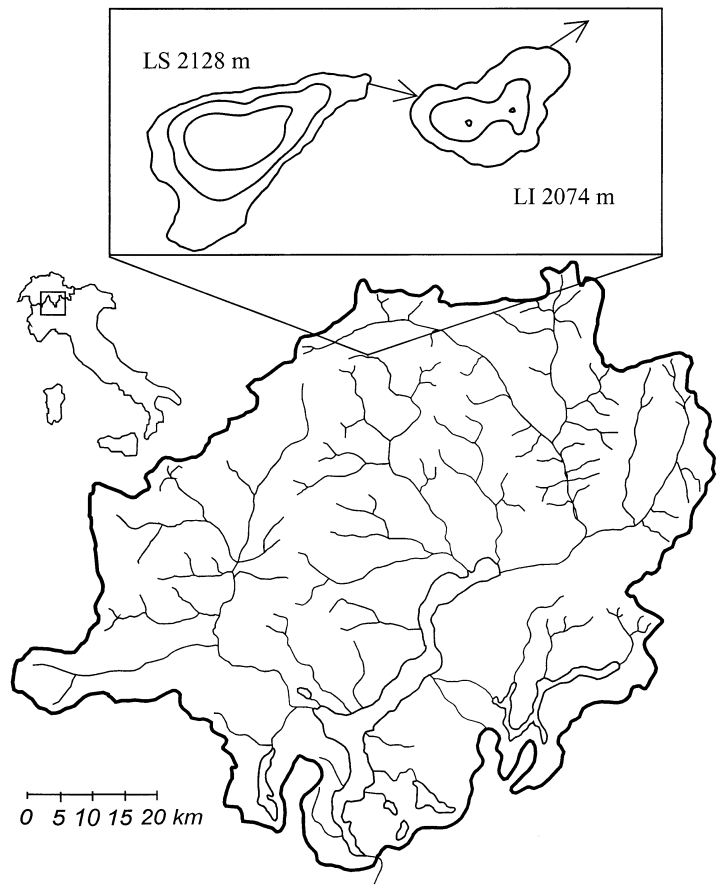

Fig. 1. Location of Laghetto Inferiore (LI) and Laghetto Superiore (LS) in the watershed of Lake Maggiore.

Tab. 1. Geographic and morphometric characteristics of Laghetto Inferiore (LI) and Laghetto Superiore (LS) and watersheds. ${ }^{(1)}$ includes the watershed of Laghetto Superiore. ${ }^{(2)}$ net waterflux through the soil.

\begin{tabular}{lccc}
\hline & & LI & LS \\
\hline Longitude & & $08^{\circ} 35^{\prime} 38^{\prime \prime}$ & $08^{\circ} 35^{\prime} 08^{\prime \prime}$ \\
Latitude & & $46^{\circ} 28^{\prime} 37^{\prime \prime}$ & $46^{\circ} 28^{\prime} 36^{\prime \prime}$ \\
Altitude & $\mathrm{m}$ & 2074 & 2128 \\
Altitude max watershed & $\mathrm{m}$ & 2648 & 2648 \\
Lake area (a) & $\mathrm{km}^{2}$ & 0.048 & 0.080 \\
Watershed area (b) & $\mathrm{km}^{2}$ & $1.78^{(1)}$ & 1.22 \\
b/a rate & & 36 & 15 \\
Maximum depth & $\mathrm{m}$ & 33 & 29 \\
Mean depth & $\mathrm{m}$ & 10.6 & 12.7 \\
Volume & $\mathrm{m}^{3} 10^{6}$ & 0.51 & 1.01 \\
Mean precipitation (prec) & $\mathrm{mm} \mathrm{y}^{-1}$ & 2416 & 2416 \\
Precipitation surplus & $\mathrm{mm} \mathrm{y}^{-1}$ & $2000^{(2)}$ & 2000 \\
Mean residence time & days & 51 & 150 \\
Origin & & glacial circle & glacial circle \\
Soil cover bedrock & & $86^{2} \%$ & $88 \%$ \\
pasture & & $7 \%$ & $6 \%$ \\
lake & & $7 \%$ & $6 \%$ \\
\hline
\end{tabular}

From the lithological point of view the lakes are located in the Penninic nappes, bordering with the Gotthard Massif and the Helvetic and Ultrahelvetic sediments (Cotti et al. 1990). The lithotype present in the watershed of LI (Fig. 2) is formed by striped gneisses (from alkali feldspars to oligoclase, from granitic to quartz dioritic), with some biotite and brown plagioclase gneiss up to micaschists. Also present are amphibolite with aplitic veins, marbles and talus material (Boggero et al. 1996). Moraines are composed of chaotic accumulations of medium to large size clasts.

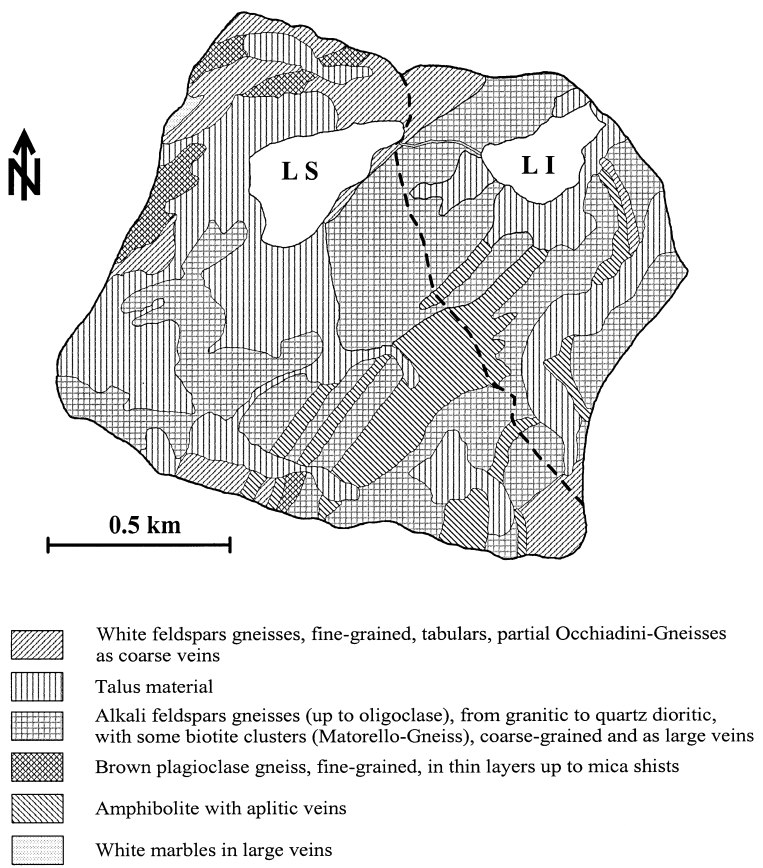

Fig. 2. Litology of the drainage basins and of the two lakes.

On the lake shore there are some small lacustrine mud deposits, of dark grey colour due to the presence of organic material. Shrubs and pastures are present in the catchment and on the mountainside to the north, not far from a snowfield. Most of the lake shore is formed of massive rocks, shaped by atmospheric events.

The bathymetric maps of the two lakes and their respective hypsographic curves are shown in figure 3.

\section{MATERIALS AND METHODS}

Atmospheric deposition was sampled weekly from May to October during 1996-1997, using a wet-only sampler. Winter precipitation from October 1996 to April 1997 was estimated by sampling a snow core; the column was subdivided into five fractions corresponding to the five heaviest snowfalls of the winter on the basis of their stratification (thickness, density and water equivalent). Sampling from LI, taken at the point of maximum depth $(33 \mathrm{~m})$, was concentrated in the lake's ice-free season (June - October) during the two years of the cycle. The lake waters were sampled on two other occasions (March 1997 and February 1998), under a layer of ice and snow about 2 metres thick. At the time of sampling, measurements of temperature, $\mathrm{pH}$, light transmittance, dissolved oxygen and conductivity were made every $0.5 \mathrm{~m}$ using a multiprobe, Idronaut mod. Ocean seven 316. Samples for chemical analysis were taken every $2.5 \mathrm{~m}$ in the water column. The dissolved oxygen concentration was also measured at these depths using Winkler's method (A.P.H.A, AWWA \& WEF 1995). 

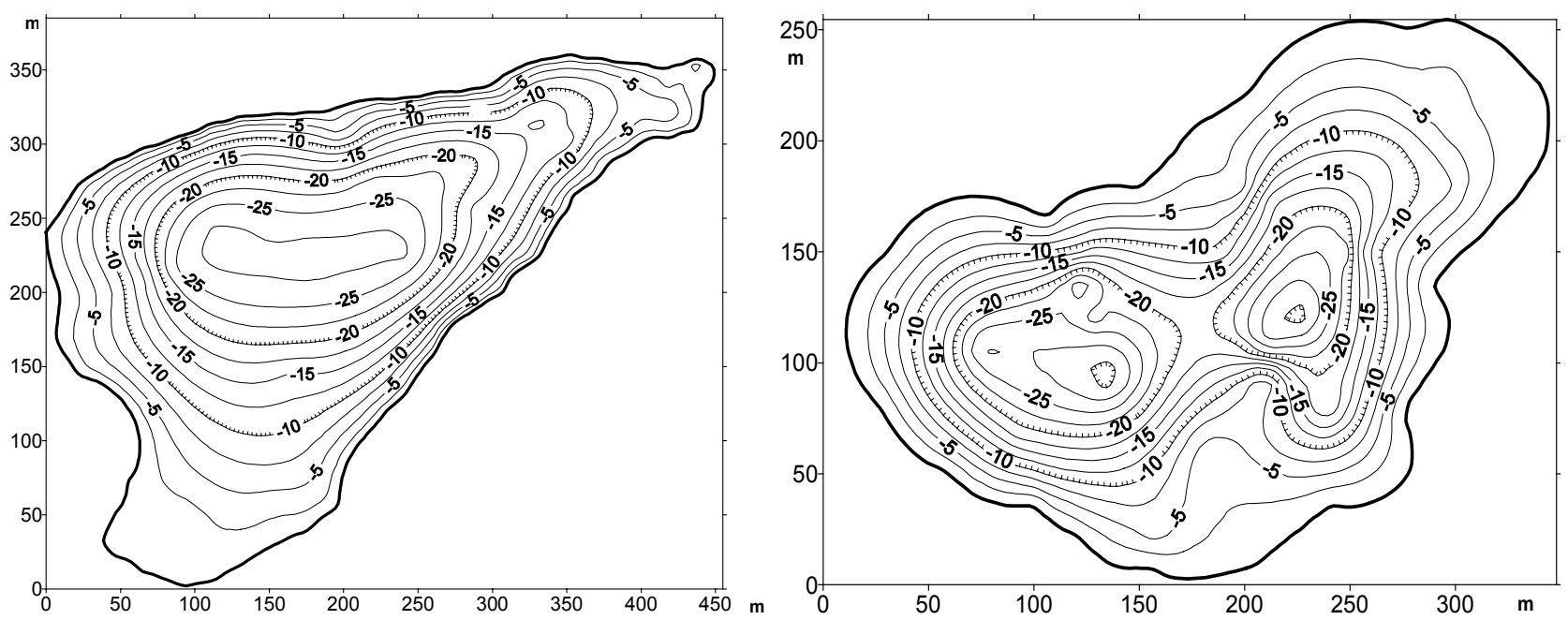

Fig. 3. Bathimetric maps of Laghetto Superiore (left) and Laghetto Inferiore (right).

Tab. 2. Analytical methods, working ranges and limits of quantification (L.O.Q.). IC: Ion chromatography; AM: automated colorimetric method.

\begin{tabular}{|c|c|c|c|c|c|}
\hline Parameter & Method & References & Unit & Working range & L.O.Q. \\
\hline Alkalinity (Alk) & $\begin{array}{l}\text { Potentiometric titration, two end points } \\
\qquad 4.5 \text { and } 4.2\end{array}$ & A.P.H.A., 1971 Rodier, 1971 & $\mu$ eq $1^{-1}$ & $1-250$ & 3 \\
\hline Conductivity (cond) & Kolrausch bridge $20^{\circ} \mathrm{C}$ & APHA-AWWA-WPCF, 1995 & $\mu \mathrm{S} \mathrm{cm}^{-1}$ & $0.2-100$ & 0.5 \\
\hline Oxygen $\left(\mathrm{O}_{2}\right)$ & Volumetric titration, Winkler method & A.P.H.A., 1971, & $\mathrm{mg} \mathrm{l}^{-1}$ & $0.5-15.0$ & 0.5 \\
\hline Sulphate $\left(\mathrm{SO}_{4}\right)$ & $\mathrm{IC}$ & $\begin{array}{l}\text { A.S.T.M., 1984, A.P.H.A., } \\
\text { 1985, Weiss, } 1986\end{array}$ & $\mathrm{mg} \mathrm{l}^{-1}$ & $0.25-4.00$ & 0.045 \\
\hline Chloride $(\mathrm{Cl})$ & $\mathrm{IC}$ & $\begin{array}{l}\text { A.S.T.M., 1984, A.P.H.A., } \\
\text { 1985, Weiss, } 1986\end{array}$ & $\mathrm{mg} \mathrm{l}^{-1}$ & $0.05-0.80$ & 0.018 \\
\hline Calcium (Ca) & IC & Weiss, 1986 & $\mathrm{mg} \mathrm{l}^{-1}$ & $0.10-4.00$ & 0.03 \\
\hline Magnesium (Mg) & $\mathrm{IC}$ & Weiss, 1986 & $\mathrm{mg} \mathrm{l}^{-1}$ & $0.02-0.80$ & 0.007 \\
\hline Sodium $(\mathrm{Na})$ & $\mathrm{IC}$ & Weiss, 1986 & $\mathrm{mg} \mathrm{l}^{-1}$ & $0.05-2.00$ & 0.013 \\
\hline Potassium (K) & $\mathrm{IC}$ & Weiss, 1986 & $\mathrm{mg} \mathrm{l}^{-1}$ & $0.05-2.00$ & 0.02 \\
\hline Ammonium $\left(\mathrm{NH}_{4}-\mathrm{N}\right)$ & AM & APHA-AWWA-WPCF, 1995 & $\mathrm{mg} \mathrm{l}^{-1}$ & $0.014-0.140$ & 0.020 \\
\hline Nitrite $\left(\mathrm{NO}_{2}-\mathrm{N}\right)$ & AM & APHA-AWWA-WPCF, 1995 & $\mu \mathrm{g} \mathrm{l}^{-1}$ & $2-20$ & 0.55 \\
\hline Nitrate $\left(\mathrm{NO}_{3}-\mathrm{N}\right)$ & $\mathrm{AM}$ & APHA-AWWA-WPCF, 1995 & $\mathrm{mg} \mathrm{l}^{-1}$ & $0.050-1.500$ & 0.015 \\
\hline Phosphate $\left(\mathrm{PO}_{4}-\mathrm{P}\right)$ & AM & APHA-AWWA-WPCF, 1995 & $\mu \mathrm{g} \mathrm{l}^{-1}$ & 6-60 & 4.3 \\
\hline Silica $\left(\mathrm{SiO}_{2}\right)$ & $\mathrm{AM}$ & APHA-AWWA-WPCF, 1995 & $\mathrm{mg} \mathrm{l}^{-1}$ & $0.3-4.0$ & 0.035 \\
\hline
\end{tabular}

Three samples were taken from the LS depth profile in summer 1997, using the same methods as for LI. To calculate the chemical budget of the lakes, their outflows were also sampled weekly from June to October 1996 and monthly during the same period in 1997.

The chemical variables considered and the methods used are listed in table 2, which also specifies the measurement range as well as the LOQ (Lower quantification limit, following the IUPAC definition (Tartari \& Mosello 1997)). The LSA participates regularly, with good results, in intercalibration exercises for analytical methods, both on rainwater and surface water samples, in the framework of the EU programme AQUACON (Analytical Quality Control and Assessment Studies in the Mediterranean Basin, Mosello et al. 1998a, b) and of ICP Assessment and monitoring of acidification of rivers and lakes (Hovind 1997, 1998).

The results obtained in this study were validated on the basis of the ionic balance and the comparison be- tween measured conductivity and that calculated from the ionic concentrations multiplied by the respective conductivity equivalents, following the methods adopted in the MOLAR programme (Mosello \& Wathne 1997).

To evaluate the trend of the lake concentrations we used the data collected from 1983 to 1997 . The comparability of the results obtained in different years in relation to changes in the analytical methods used was examined by Boggero et al. $(1996,1998)$.

The water density profile in LI is shown as density anomaly, defined as the difference between the actual density of the lake water $\left(\rho, \mathrm{g} \mathrm{cm}^{-3}\right)$ and the density of pure water at $3.98{ }^{\circ} \mathrm{C}$, assumed as $1 \mathrm{~g} \mathrm{~cm}^{-3}$. $\rho$ is calculated from the temperature and using the table of absolute density of water (Weast 1970) and from the solute concentrations $\left(\mathrm{mg} \mathrm{l}^{-1}\right.$ ) of $\mathrm{Ca}, \mathrm{Mg}, \mathrm{Na}, \mathrm{K}, \mathrm{SO}_{4}, \mathrm{NO}_{3}, \mathrm{Cl}$, $\mathrm{NH}_{4}$ and $\mathrm{SiO}_{2}$. 
The annual hydrological balance of the lake was evaluated on the basis of measurements of the amount of deposition, performed in the meteorological station of Robiei, about $7 \mathrm{~km}$ from the sampled lakes. The approach used was that proposed for the Swiss Alps by Rihm et al. (1994).

The mass balance calculation is based on the continuity equation. Such equation can be differently formulated but the common concept is condensed in the statement that the sum of all (positive and negative) fluxes of given substances $\mathrm{M}$ equals zero, i.e.:

$$
\sum_{1}^{r} m_{r}=0
$$

Another form of the same statement may be written as (Vollenweider 1975):

$\frac{d(M) \text { content }}{d t}+\frac{d(M) \text { input }}{d t}+\frac{d(M) \text { output }}{d t}+\frac{d(M) \text { exchange }}{d t}=0$

This second equation makes it easy to distinguish between non-conservative and conservative substances; for the latter, the exchange term becomes zero.

\section{RESULTS AND DISCUSSION}

\subsection{Atmospheric deposition chemistry}

Volumes of precipitation in the two study years (Fig. 4) show marked variability in the monthly distribution of the wet deposition, with extreme values ranging from 0 to $500 \mathrm{~mm}$. A comparison with the pluriannual mean (1991-1996) reveals an appreciable difference in the mean monthly values. Nevertheless, the volume collected is the same for both years $\left(2280 \mathrm{~mm} \mathrm{y}^{-1}\right)$, and is fairly close to the mean annual volume of the period 1991-1996 (2467 $\left.\mathrm{mm} \mathrm{y}^{-1}\right)$.

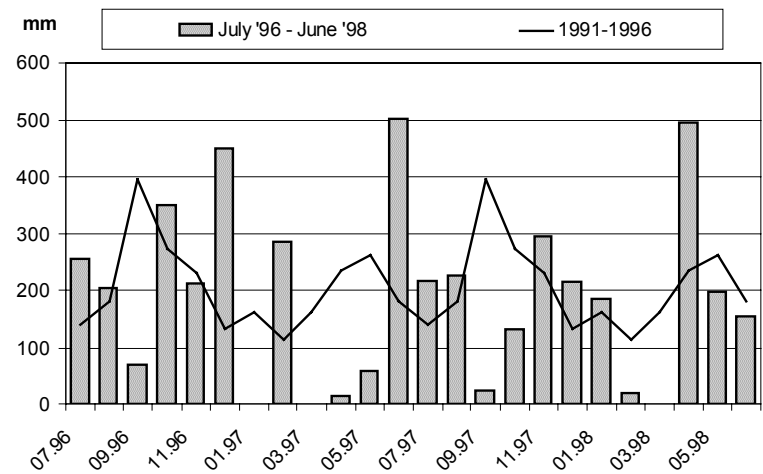

Fig. 4. Monthly precipitation (1996-1998) compared to the average 1991-1996 at Robiei.

The mean monthly values of acidity (Tab. 3) are slightly higher in summer (June-October: $\mathrm{pH}$ 4.8-5.2) than in winter deposition (November-May: $\mathrm{pH}$ 5.2-5.6); the concentrations of the other solutes, in particular sulphate, nitrate and ammonium, are also higher in summer than winter. Alkalinity, assumed to be entirely due to
$\mathrm{HCO}_{3}{ }^{-}$, and calcium are present in high values only in May (Tab. 3), coinciding with precipitation containing sand from the Sahara, which left unmistakable coloured dust during filtration. These variations also emerge noticeably in the mean rain and snow concentrations (Fig. 5). The marked differences between them reflect the greater influence of the air masses coming from the south-south-west, which are more frequent from April to October, when the layer of the atmosphere in circulation is above $2000 \mathrm{~m}$ a.s.l., than in winter, when the atmosphere is stratified below an altitude of 800-1200 m. The different composition of ions in precipitation from the south is mainly reflected in the concentrations of sodium, chloride and magnesium of marine origin, which are higher in summer and almost absent in winter. Taking into account the fact that the deposition volumes of rain and snow are similar (respectively 1232 and 1196 $\mathrm{mm}$ ), we calculated a mean concentration of atmospheric deposition and compared this with the lake water concentrations (Tab. 3). The results show a mean annual total ionic concentration of $80 \mu \mathrm{eq} \mathrm{l}^{-1}$, compared with that of the lake water $\left(200 \mu \mathrm{eq} 1^{-1}\right)$ and very different ionic composition:

$$
\begin{aligned}
& \text { rain: } \mathrm{SO}_{4}{ }^{2-}>\mathrm{NH}_{4}{ }^{+} \geq \mathrm{NO}_{3}{ }^{-}>\mathrm{Ca}^{2+}>\mathrm{H}^{+}>\mathrm{Mg}^{2+} \geq \mathrm{Na}^{+} \geq \\
& \mathrm{Cl}^{-}>\mathrm{K}^{+} \\
& \text {lake: } \mathrm{Ca}^{2+}>\mathrm{SO}_{4}{ }^{2-} \geq \mathrm{Alc}^{-}>\mathrm{NO}_{3}{ }^{-}>\mathrm{Na}^{+}>\mathrm{K}^{+}>\mathrm{Mg}^{2+}> \\
& \mathrm{Cl}^{-}
\end{aligned}
$$

\subsection{LI temperature and chemistry}

During each summer (July-August) the surface water temperature varies between $14{ }^{\circ} \mathrm{C}$ and $18{ }^{\circ} \mathrm{C}$, and the water is warmed to a depth of $15 \mathrm{~m}$. During the cold period (September-June) the temperature of the surface layers falls from around $8{ }^{\circ} \mathrm{C}$ in September to $4{ }^{\circ} \mathrm{C}$ in October (Fig. 6), and reaches values between $4{ }^{\circ} \mathrm{C}$ and 0 ${ }^{\circ} \mathrm{C}$ in the winter, rising to around $4{ }^{\circ} \mathrm{C}$ again in June. The temperatures of the deepest layers (between 15-32 m) remain close to $4.2{ }^{\circ} \mathrm{C}$ throughout the year. The period of ice-cover is from mid-October to June.

Over the two years of the study, dissolved oxygen (Fig. 7) was always well saturated (90-100\%), with a relative maximum in August at a depth of around $15 \mathrm{~m}$.

The lake water chemistry (Tab. 4) is considerably affected by the atmospheric deposition, which is largely responsible for the nitrate and sulphate concentrations (Boggero et al. 1996). On the other hand, weathering phenomena neutralise atmospheric acidity, in its free form (hydrogen ion) and in the form freed by the oxidation of ammonium (Van Breemen et al. 1984). Concentrations of the latter ion, which is important in atmospheric deposition, are in fact almost negligible in the lake waters.

Weathering produces a small reserve of alkalinity, with values always above $30 \mu \mathrm{eq} \mathrm{l}^{-1}$ and increasing with depth (from 30 to $90 \mu$ eq $1^{-1}$, Fig. 8). In June 1997 a very heavy rainfall, occurring after the end of the snowmelt in the watershed, brought about an almost complete cir- 
Tab. 3. Monthly weighted means of the precipitation $(\mathrm{mm})$, values of $\mathrm{pH}$, conductivity $\left(\mu \mathrm{S} \mathrm{cm}^{-1}\right)$, acidity $\left(\mathrm{H}^{+}\right)$and ions concentrations ( $\mu$ eq $1^{-1}$ ) in the period July 1996 - June 1998.

\begin{tabular}{|c|c|c|c|c|c|c|c|c|c|c|c|c|c|c|c|}
\hline & prec & $\mathrm{pH}$ & cond & $\mathrm{H}^{+}$ & $\mathrm{Ca}^{2+}$ & $\mathrm{Mg}^{2+}$ & $\mathrm{Na}^{+}$ & $\mathrm{K}^{+}$ & $\mathrm{NH}_{4}^{+}$ & $\mathrm{HCO}_{3}^{-}$ & $\mathrm{SO}_{4}{ }^{2-}$ & $\mathrm{NO}_{3}^{-}$ & $\mathrm{Cl}^{-}$ & Anions & Cations \\
\hline Jan & 93 & 5.65 & 2.7 & 2.2 & 10.9 & 1.5 & 2.1 & 0.6 & 0.0 & 3.0 & 4.4 & 5.0 & 2.1 & 14.5 & 17.3 \\
\hline Feb & 154 & 5.10 & 4.1 & 7.8 & 1.4 & 0.1 & 0.1 & 0.1 & 2.9 & 0.0 & 4.3 & 5.7 & 0.1 & 10.0 & 12.4 \\
\hline Mar & 0 & & & & & & & & & & & & & & \\
\hline Apr & 254 & 5.14 & 5.5 & 7.8 & 11.1 & 2.1 & 1.9 & 0.5 & 0.5 & 0.0 & 9.2 & 10.4 & 1.2 & 20.8 & 23.9 \\
\hline May & 127 & 5.38 & 13.6 & 2.7 & 53.2 & 6.5 & 10.9 & 1.7 & 52.5 & 24.0 & 47.4 & 27.8 & 6.2 & 105.3 & 127.5 \\
\hline Jun & 328 & 5.18 & 10.3 & 11.7 & 10.5 & 1.4 & 3.5 & 0.6 & 25.5 & 1.1 & 27.8 & 19.1 & 2.3 & 50.3 & 53.2 \\
\hline Jul & 236 & 5.08 & 10.8 & 14.4 & 17.6 & 5.9 & 5.0 & 1.8 & 20.2 & 0.5 & 57.0 & 17.9 & 7.4 & 82.9 & 65.0 \\
\hline Aug & 215 & 5.10 & 8.8 & 11.8 & 9.9 & 4.7 & 2.6 & 0.5 & 24.4 & 0.1 & 32.0 & 12.9 & 4.5 & 49.5 & 53.8 \\
\hline Sep & 46 & 5.16 & 10.2 & 8.8 & 19.2 & 9.9 & 2.5 & 0.6 & 24.1 & 0.5 & 34.2 & 25.3 & 3.5 & 63.5 & 65.2 \\
\hline Oct & 241 & 4.80 & 10.3 & 15.8 & 7.3 & 3.3 & 5.3 & 1.1 & 19.1 & 0.0 & 25.4 & 25.8 & 2.5 & 53.7 & 52.0 \\
\hline Nov & 254 & 5.28 & 3.7 & 5.2 & 5.6 & 0.8 & 0.7 & 0.5 & 2.7 & 0.0 & 5.7 & 6.1 & 1.6 & 13.3 & 15.5 \\
\hline Dec & 333 & 5.26 & 3.4 & 5.9 & 3.8 & 0.4 & 0.5 & 0.3 & 1.2 & 0.0 & 2.6 & 5.0 & 0.7 & 8.3 & 12.0 \\
\hline mean & 2279 & 5.19 & 7.4 & 9.2 & 11.4 & 2.6 & 2.9 & 0.7 & 14.2 & 1.7 & 21.4 & 13.7 & 2.7 & 39.6 & 41.1 \\
\hline
\end{tabular}

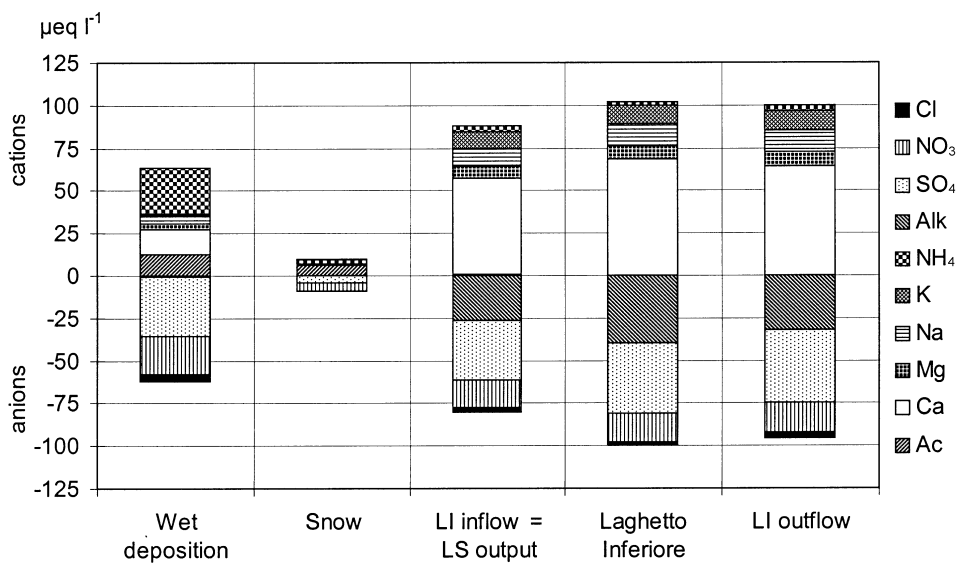

Fig. 5. Chemical characteristics in: atmospheric depositions (rain and snow), inflow and outflow, Laghetto Superiore and Laghetto Inferiore.

culation and lake turnover, also causing a temporary decrease of alkalinity in the water column (from 41 to 29

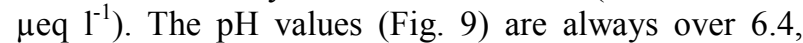
with a range of variation from 6.4-7.0; the highest values $(>6.8)$ are found in August-September, in the deepest layers $(15-20 \mathrm{~m})$, coinciding with the oxygen maxima. Calcium $\left(70 \mu \mathrm{eq} \mathrm{l}^{-1}\right)$ dominates the cations, followed by sodium and potassium (respectively 14 and $11 \mu$ eq $1^{-1}$; Tab. 4); sulphate concentrations are very similar to alkalinity values. The total solute concentration in LI is on average low ( $c$ a $200 \mu \mathrm{eq} \mathrm{l}^{-1} \pm 10 \%$ ) with a mean conductivity value of $12.5 \mu \mathrm{S} \mathrm{cm}^{-1}$ at $20^{\circ} \mathrm{C}$.

The other main chemical variables in solution also show variations similar to that described for alkalinity, with concentrations increasing with depth between 60 and $120 \mu \mathrm{eq} \mathrm{l}^{-1}$ for $\mathrm{Ca}$, between 30 and $80 \mu \mathrm{eq} \mathrm{l}^{-1}$ for $\mathrm{SO}_{4}, 15$ and $18 \mu$ eq $\mathrm{l}^{-1}$ for $\mathrm{NO}_{3}$ and between 10 and 20 $\mu$ mole $1^{-1}$ for $\mathrm{SiO}_{2}$. The total solute concentration increases progressively with depth, showing values of 180 $\mu$ eq $\mathrm{l}^{-1}$ at the surface and $300 \mu \mathrm{eq} \mathrm{l}^{-1}$ at $25 \mathrm{~m}$ depth.

As regards nutrients (Tab. 4), reactive and total phosphorous were below the LOQ (Tab. 2) in lake water, but were quantifiable as particulate $\mathrm{P}\left(1-2 \mu \mathrm{g} \mathrm{P}^{-1}\right)$, obtained by filtering 1 litre of water. Nitrate was the dominant form of dissolved nitrogen $\left(16 \mu \mathrm{eq} \mathrm{l}^{-1}\right)$ showing only small seasonal variation. Total nitrogen averaged $340 \mu \mathrm{g} \mathrm{l}^{-1}\left(24.4 \mu \mathrm{mol} \mathrm{l} \mathrm{l}^{-1}\right)$, indicating an organic

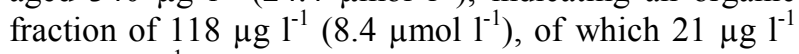
$\left(1.5 \mu \mathrm{mol} \mathrm{l}^{-1}\right)$ was particulated organic $\mathrm{N}$.

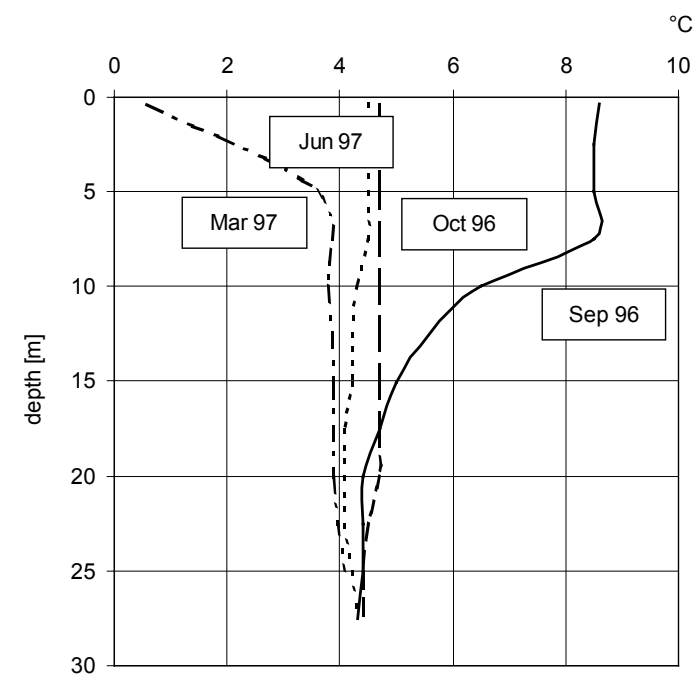

Fig. 6. Seasonal profiles of temperature in Laghetto Inferiore. 

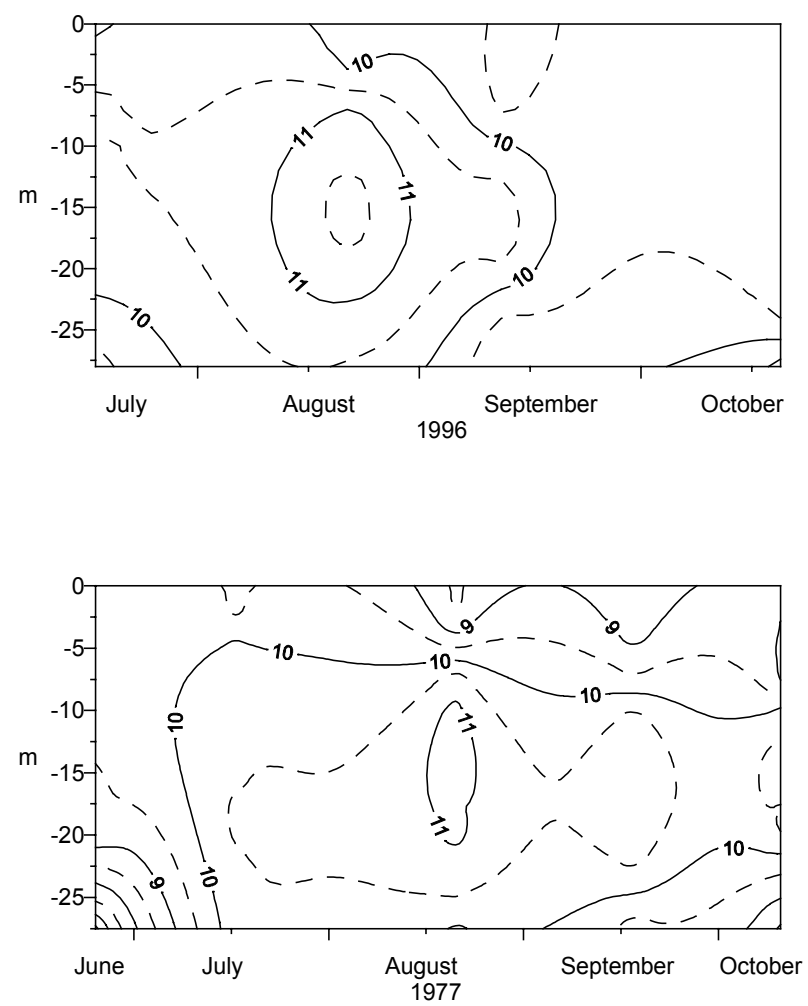

Fig. 7. Seasonal variations of oxygen $\left(\mathrm{mg} \mathrm{l}^{-1}\right)$ in Laghetto Inferiore during 1996 and 1997. monium, while nitrate concentrations remain at the same level as those in atmospheric deposition. The ionic concentration of LI waters is slightly higher than in the inflowing water, mainly because of the increase of calcium and alkalinity.

\subsection{LI water density}

The profile of water density anomaly in LI (Fig. 10) in the upper $15 \mathrm{~m}$ is regulated by temperature (Fig. 6). In fact, during the summer the surface water is warmed and its density decreases, stabilising the water column. In contrast, during the frosty period (October-June) the surface layers cool, and when the temperature falls below $3.98{ }^{\circ} \mathrm{C}$ the water density decreases; in this case too the water column is stabilised. On the other hand the density of the water layer below $20 \mathrm{~m}$, which shows slight variations in temperature, is mainly regulated by ion content. The most favourable time for the circulation is during the periods of homothermia, which are however very short. In these situations, too, the vertical saline gradient seems to be able to stabilise the deep layers of the column, and only the occurrence of extreme meteorological and/or hydrological situations appears to be able to destabilise the vertical stratification. For example, a particularly intense (more than $500 \mathrm{~mm}$ ) rainfall event occurring at the end of June 1997 (Fig. 4), when the lake was still in a condition of homothermia, caused a partial mixing and a dilution of the water, re-

Tab. 4. Weighted mean values of temperature, $\mathrm{pH}$, oxygen $\left(\mathrm{mg} \mathrm{l}^{-1}\right)$, conductivity $\left.(\mu \mathrm{S} \mathrm{cm})^{-1}\right)$, ion concentrations $\left(\mu \mathrm{eq}^{-1}\right)$, reactive phosphorus and silica $\left(\mu \mathrm{g}^{-1}\right)$, particulated phosphorus and nitrogen $(\mu \mathrm{g}$ $\left.\mathrm{l}^{-1}\right)$, total phosphorus and nitrogen $\left(\mu \mathrm{g} \mathrm{l}^{-1}\right)$ of Laghetto Inferiore (1996-1999).

\begin{tabular}{lccccccc}
\hline & 16.7 .96 & 18.10 .96 & 18.3 .97 & 9.10 .97 & 19.2 .98 & 22.7 .98 & 15.2 .99 \\
\hline Temperature & 7.18 & 4.54 & 3.01 & 7.39 & 3.18 & 6.28 & 3.09 \\
Dissolved oxygen & 10.00 & 9.54 & 9.38 & 9.25 & - & 9.04 & 8.38 \\
$\mathrm{pH}$ & 6.34 & 6.21 & 6.39 & 6.39 & 6.26 & 6.43 & 6.26 \\
Conductivity, 20 ${ }^{\circ} \mathrm{C}$ & 12.3 & 13.8 & 14.2 & 11.1 & 12.4 & 11.1 & 12.2 \\
Calcium & 60.2 & 74.6 & 76.7 & 67.8 & 72.6 & 60.72 & 81.1 \\
Magnesium & 7.2 & 8.8 & 9.2 & 9.2 & 9.5 & 8.0 & 10.1 \\
Sodium & 13.0 & 13.6 & 13.2 & 12.2 & 15.1 & 12.0 & 17.2 \\
Potassium & 10.3 & 11.5 & 11.5 & 11.0 & 12.3 & 10.5 & 12.7 \\
Alkalinity & 32.1 & 46.9 & 47.0 & 33.0 & 39.6 & 33.3 & 45.3 \\
Sulphate & 39.6 & 43.1 & 46.5 & 39.4 & 43.3 & 37.6 & 44.3 \\
Chloride & 2.9 & 2.5 & 2.3 & 1.9 & 3.2 & 3.1 & 2.8 \\
Ammonium & 1.2 & 2.9 & 0.4 & 0.3 & 0.1 & 1.9 & 0.1 \\
Nitrite & 0.1 & 0.2 & 0.0 & 0.1 & 0.0 & 0.1 & 0.1 \\
Nitrate & 15.5 & 16.2 & 17.4 & 14.7 & 16.5 & 16.6 & 19.7 \\
Anions & 90.2 & 109.0 & 115.0 & 89.1 & 104.2 & 90.7 & 112.1 \\
Cations & 91.9 & 111.5 & 114.2 & 100.5 & 111.7 & 93.0 & 122.7 \\
Particulted nitrogen & 13 & 20 & 14 & 21 & 30 & 13 & - \\
Total nitrogen & 252 & 356 & - & 364 & - & 392 & - \\
Reactive phosphorus & 1.8 & 1.4 & 2.1 & 0.5 & - & 0.6 & -
\end{tabular}

The inflowing water to LI displays characteristics which are somewhat different from those of the atmospheric deposition (Fig. 5 ): acidity has completely disappeared and alkalinity (around $25 \mu \mathrm{eq} \mathrm{l}^{-1}$ ) is present. Also the inflowing water shows a total absence of am- ducing the mean ionic concentration from 205 to 170 $\mu$ eq $1^{-1}$. After this phenomenon the vertical saline gradient quickly recovered, and by July the lake had returned to its previous condition of stability (Fig. 10). 

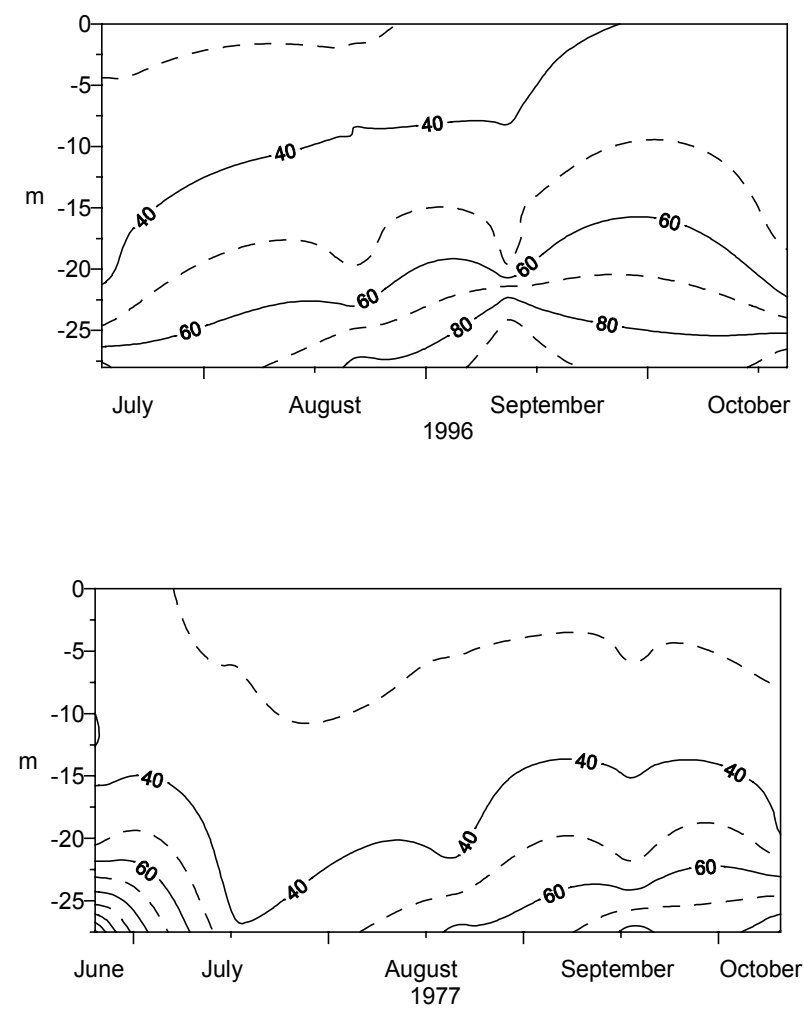

Fig. 8. Seasonal variations of alkalinity $\left(\mu \mathrm{eq} \mathrm{l}^{-1}\right)$ in Laghetto Inferiore during 1996 and 1997.
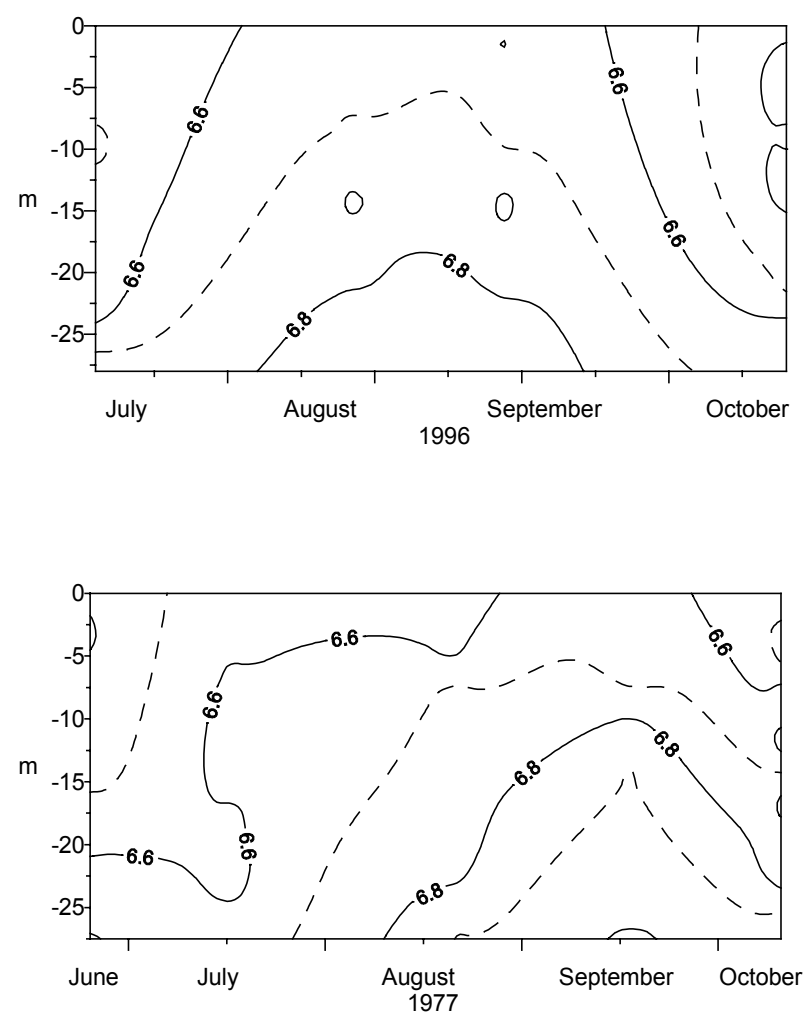

Fig. 9. Seasonal variations of and $\mathrm{pH}$ in Laghetto Inferiore during 1996 and 1997.

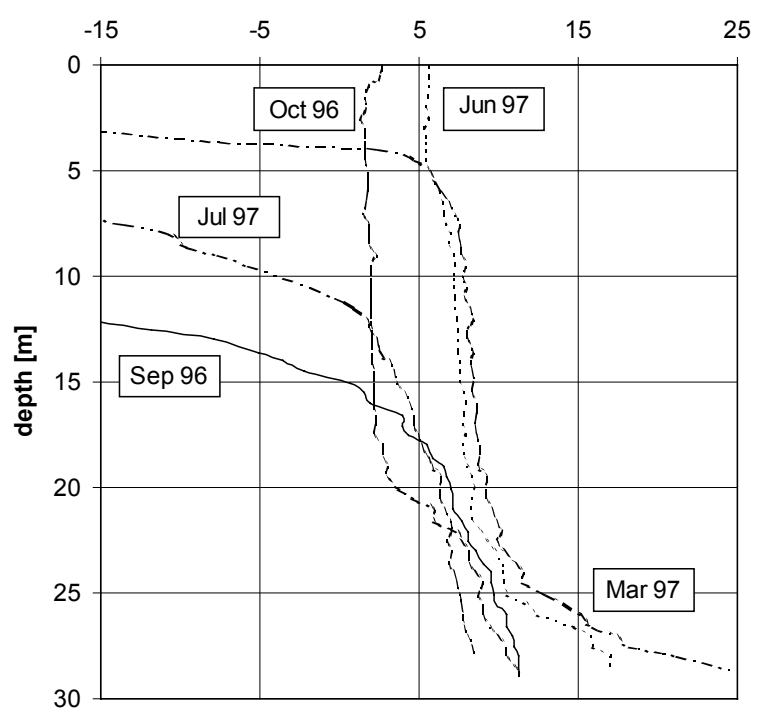

Fig. 10. Seasonal profiles of density anomaly $\left(\mathrm{mg} \mathrm{l}^{-1}\right)$ in Laghetto Inferiore

\subsection{Chemical budget and weathering}

The mass budget has been calculated on the basis of the continuity equation, which takes account of the atmospheric input and the contribution from the outflow of LS. In the study period the variations in the total ionic content of the water were $\pm 14 \%$ (Tab. 4). In both lake catchments the weathering rates were similar, showing an appreciable increase in basic cations, alkalinity, sulphate and silica (Tab. 4). Chloride and nitrate did not show significant variations between input and output.

The flux of ions in the LS and LI catchments is shown in table 5 and figure 11 . The overall flux of ions deriving from deposition is $147 \mathrm{meq} \mathrm{m}^{-2} \mathrm{y}^{-1}$, while the flux leaving LI, that is, including weathering, is slightly more than $390 \mathrm{meq} \mathrm{m} \mathrm{m}^{-2}$. The most marked variations are those of the disappearance of acidity and ammonium and the presence of alkalinity in the outflowing waters.

Altogether the weathering processes in the watershed of LS are able to neutralise an acidity of $18 \mathrm{meq}$ $\mathrm{m}^{-2} \mathrm{y}^{-1}$, to which must be added the acidity deriving from the transformations of the ammonium ion falling in atmospheric deposition (24 meq $\mathrm{m}^{-2} \mathrm{y}^{-1}$ ). This may vary from 1 to 2 moles of acidity produced per mole of ammonium consumed, according to whether the transformation is caused by uptake from the vegetation crop in the watershed (1 mole), or from oxidation to nitrate (2 moles) (Schuurkes \& Mosello 1988; Van Breemen et al. 1984).

The overall quantity of neutralised acidity thus ranges between 42 and $66 \mathrm{meq}^{-2} \mathrm{y}^{-1}$. To this quantity must be added the alkalinity in the water flowing from LS (52 meq $\left.\mathrm{m}^{-2} \mathrm{y}^{-1}\right)$ and from the LI system (64 meq $\mathrm{m}^{-2}$ $\left.\mathrm{y}^{-1}\right)$, which brings the overall quantity of potentially 
Tab. 5. Fluxes balance of Laghetto Superiore (LS) and Laghetto Inferiore (LI); ions (meq $\mathrm{m}^{-2}$ $\left.\mathrm{y}^{-1}\right)$ silica $\left(\mathrm{mmole} \mathrm{m}^{-2} \mathrm{y}^{-1}\right)$.

\begin{tabular}{|c|c|c|c|c|c|c|}
\hline & \multicolumn{2}{|c|}{ Input } & \multicolumn{2}{|c|}{ Output } & \multicolumn{2}{|c|}{ Input-Output } \\
\hline & Rain & Snow & LS & LI & $\mathrm{LS}$ & LI \\
\hline Acidity & 13.1 & 5.8 & 1 & 1 & -18 & -18 \\
\hline Calcium & 14.7 & 1.0 & 113 & 128 & 97 & 113 \\
\hline Magnesium & 4.0 & 0.0 & 15 & 16 & 11 & 12 \\
\hline Sodium & 4.5 & 0.0 & 21 & 25 & 17 & 20 \\
\hline Potassium & 1.0 & 0.0 & 19 & 24 & 18 & 23 \\
\hline Ammonium & 27.4 & 2.9 & 6 & 7 & -24 & -24 \\
\hline Alkalinity & 0.6 & 0.0 & 53 & 65 & 52 & 64 \\
\hline Sulphate & 35.9 & 3.9 & 70 & 85 & 30 & 45 \\
\hline Nitrate & 23.1 & 4.9 & 32 & 35 & 4 & 7 \\
\hline Chloride & 3.9 & 0.0 & 6 & 7 & 2 & 3 \\
\hline Cations & 64.8 & 9.7 & 175 & 200 & 101 & 125 \\
\hline Anions & 63.5 & 8.8 & 161 & 191 & 88 & 119 \\
\hline Reactive silica & 0.0 & 0.0 & 18 & 21 & 18 & 21 \\
\hline
\end{tabular}
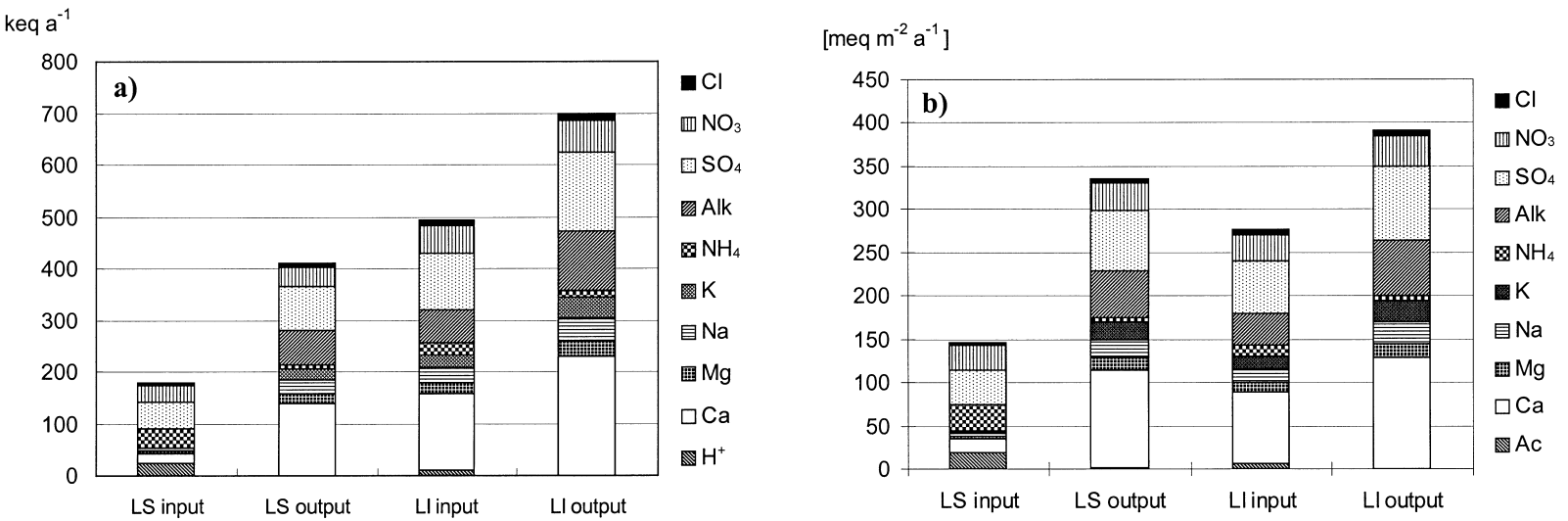

Fig. 11: Mass balance (a) and fluxes (b) of ions in the system LS and LI. LS input: atmospheric load to the watershed of LS; it does not include weathering. LI input: includes LS output and atmospheric loads to the watershed of LI: it does not include weathering of LI watershed. LS and LI output: loads leaving the lakes through the outlets.

neutralisable acidity to values of $94-118 \mathrm{meq}^{-2} \mathrm{y}^{-1}$ for LS and 106-130 meq $\mathrm{m}^{-2} \mathrm{y}^{-1}$ for LI.

This means that at least $50 \%$ of the potential alkalinity that the rocks in the watershed can release has been consumed by atmospheric deposition acidity.

\subsection{Long-term trend}

The long-term trend in the chemical components of LI provides an insight into the extent of recovery from the impact of acidification on Alpine lakes. The main chemical parameters of LI, measured since 1985, show an increase in $\mathrm{pH}$ and alkalinity values, while there is a decrease in sulphate and nitrate (Fig. 12). However, these results refer to samples taken near the surface $(-1$ $\mathrm{m})$ towards the end of the summer, when the neutralising action of the weathering has reached its maximum. Compared with a series of 21 Alpine lakes sampled at three-yearly intervals in the Maggia valley (Boggero et al. 1996), LI shows a slightly increasing trend of $\mathrm{pH}$ and alkalinity, contrasted with a decreasing trend of nitrate and sulphate. These trends are justified by similar variations found in atmospheric deposition in Ticino
(Boggero 1998; Barbieri 1999); while these refer to stations located at low altitudes, they suggest that the decrease of deposition acidity has also affected higher altitudes. The decrease in the deposition has not affected the loading of inorganic nitrogen; the decrease which, in contrast, is observable in the water of LI is probably the effect of a greater nitrogen consumption by in-lake processes and/or by vegetation uptake in the catchment. A similar decline in nitrate in high-altitude lakes has been found in the nearby Ossola Valley (Boggero et al. 1996) and constitutes a general trend on a European scale (Mosello et al. 1999), with particular reference to highaltitude lakes (The MOLAR Water Chemistry Group 1999).

\section{CONCLUSIONS}

Despite the high loading of acidifying pollutants to LS and LI catchments, weathering processes are sufficient to completely neutralise these inputs. The deposition of pollutants occurs mainly in late spring and summer, with snow having the lowest pollutant concentrations. This is due to stratification of the atmosphere, 
which greatly limits the transport of pollutants from the plain during the winter.
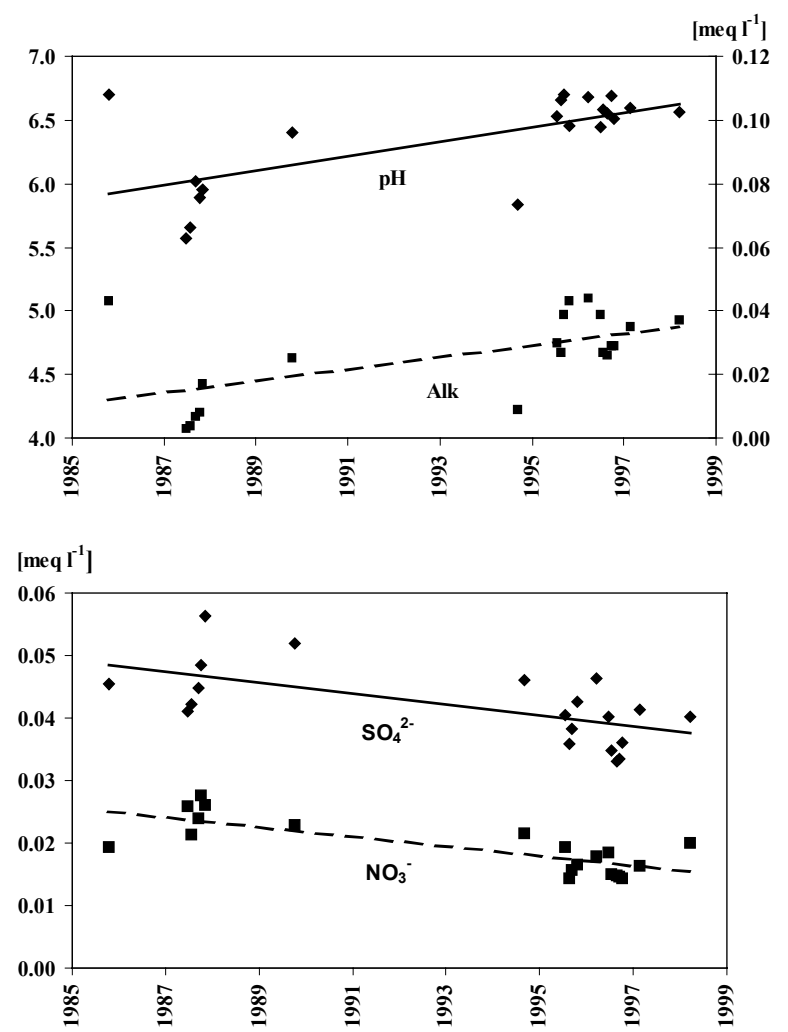

Fig. 12. Trends of $\mathrm{pH}$, alkalinity, sulphate and nitrate in Laghetto Inferiore (-0.4 m depth).

A considerable contribution to acid deposition also derives from ammonium, which is one of the main ions in the atmospheric deposition, though almost absent in the lake waters. Taking account of the total acidity of the deposition, and the alkalinity which is finally present in the lake waters, we estimated that an alkalinity value of $94-130$ meq $\mathrm{m}^{-2} \mathrm{y}^{-1}$ is released by weathering from the rocks of the watershed; more than $50 \%$ of this alkalinity is neutralised by the acidity of the deposition.

A study of the stratification of the lake reveals a solute gradient which could be stable over a period of months. The density profile of LI is determined mainly by temperature, which results in a relatively stable water column. The mixing of the lake water may be heavily influenced by intense precipitation events (400-500 $\mathrm{mm}$ ) during the short periods of homothermia (2-3 weeks a year). However, on these occasions the saline gradient, a characteristic of the bottom layer, is able to inhibit a complete circulation. On the other hand, the nutrient concentrations and higher alkalinity of the deep waters may considerably affect algal production, which in Alpine lakes is highest close to the bottom, if it gets enough light.

These results highlight the need for more detailed studies on the physics of Alpine lakes, especially those with a maximum depth greater than 20-30 m, or which, owing to the configuration of the watershed, are particularly sheltered from the wind. The homogenisation of the water is in fact an important process which allows the redistribution of both algal nutrients and other ions present in the water.

The decreased impact of acidic atmospheric depositions may have far-reaching ecological consequences. An important line is that of possible variations in plankton populations, which have already been a focus of study in recent years (Simona et al. 1999). But it is in the study of the effects of climatic variations on aquatic ecosystems, and more generally on the Alpine environment, that Alpine lakes, especially those for which we have a large amount of information, can be particularly useful, thanks to their sensitivity to environmental factors and the low human impact to which they are exposed. Continuous monitoring is therefore vital, as is more detailed study of the phenomena which are most likely to be sensitive to variations in the atmospheric temperature, such as the weathering of ions in the watershed, and the biological processes both in the lakes and in the vegetation covering the watershed.

\section{ACKNOWLEDGMENTS}

We are very grateful to Dr Ron Harriman, Freshwater Fisheries Laboratory, Faskally, Pitlochry, Scotland, for his criticisms and suggestions which greatly improved this paper. Its defects and limitations remain the responsibility of the authors.

\section{REFERENCES}

A.P.H.A, AWWA \& WEF. 1995. Standard methods for the examination of water and wastewater. 19th ed. American Public Health Association, Washington.

Barbieri, A., M. Veronesi, M. Simona, S. Malusardi \& V. Straskrabova, 1999. Limnological survey in eight mountain lakes located in the Lago Maggiore watershed (Switzerland). J. Limnol., 58(2): 179-192.

Barbieri, A. \& G. Righetti. 1987. Chimica delle deposizioni atmosferiche nel Cantone Ticino ed effetti sulle acque dei laghi alpini d'alta quota. Documenta Ist. ital. Idrobiol., 14: 19-34.

Boggero, A., A. Marchetto, A. Barbieri, A. Sassi, M. Conedera, G.A. Tartari \& R. Mosello. 1996. Idrochimica dei laghi alpini del Canton Ticino (Alpi Centrali) in relazione con la chimica delle precipitazioni. Documenta Ist. ital. Idrobiol., 57: 273 pp.

Boggero, A., A. Barbieri, J. de Jong, A. Marchetto \& R. Mosello. 1998. Chemistry and critical loads of Alpine lakes in Canton Ticino /Southern Central Alps). Aquatic Sciences, 60: 300-315.

Camarero, L., J. Catalan, A. Boggero, A. Marchetto, R. Mosello \& R. Psenner. 1995. Acidification in high mountain lakes in Central, Southwest and Southeast Europe (Alps, Pyrenees, Pirin). Limnologica, 25: 141-156.

Cotti G., M. Felber, A. Fossati, G. Lucchini, E. Steiger \& P.L. Zanon. 1990. Introduzione al paesaggio naturale del Cantone Ticino. 1. Le componenti naturali. Dipartimento dell'Ambiente, Bellinzona. ISBN: 88-85115-14-4.

Giovanoli, R., J.L. Schnoor, L. Sigg, W. Stumm \& J. Zobrist. 1988. Chemical weathering of crystalline rocks in the 
catchment area of acidic Ticino lakes, Switzerland. Clays Clay Miner., 36: 521-529.

Hovind, H. 1997. Intercalibration 9711. pH, conductivity, alkalinity, nitrate+nitrite, chloride, sulfate, calcium, magnesium, sodium, potassium, total aluminium, aluminium-reactive and non-labile, dissolved organic carbon, and chemical oxygen demand. NIVA Report, ISBN 82-5773284-2, Oslo: $57 \mathrm{pp}$.

Hovind, H. 1998. Intercalibration 9812. pH, conductivity, alkalinity, nitrate+nitrite, chloride, sulphate, calcium, magnesium, sodium, potassium, total aluminium, aluminiumreactive and nonlabile, TOC and COD-Mn. NIVA ICPWaters Report 49/1998, ISBN 82-577-3530-2, Oslo: 59 pp.

Marchetto, A., R. Mosello \& G.A. Tartari. 1991. Acidification of Alpine lakes in Ossola Valley (Italy). In: Bhatt, S.D. \& R.K. Pande (Eds), Ecology of Mountain Waters. Ashish Publ., New Delhi: 75-91.

Marchetto, A., R. Mosello, R. Psenner, G. Bendetta, A. Boggero, D. Tait \& G.A. Tartari. 1995. Factors affecting water chemistry of alpine lakes. Aquatic Sciences, 55: 81-89.

Marchetto, A., A. Boggero, M.C. Brizzio, R. Mosello \& A. Barbieri. 1998. Nitrogen content in atmospheric deposition and headwater lakes in the Lake Maggiore drainage basin. In: Tappeiner, U., F.V. Ruffini \& M. Fumai (Eds), Hydrology, Water Resources and Ecology of Mountain Areas. Proc. HeadWater '98 Conference, Meran/Merano (Italy), 20-23 April 1998: 218-221.

Mosello, R., A. Boggero, M. Carmine, A. Marchetto, A. Sassi \& G.A. Tartari. 1994. Ricerche idrochimiche sui laghi delle valli Ossola e Sesia (Alpi Pennine e Lepontine). Documenta Ist. ital. Idrobiol., 46: 436 pp.

Mosello, R., B.M. Wathne, L. Lien \& H.J.B. Birks. 1995. AL:PE projects: water chemistry and critical loads. Water Air Soil Pollution, 85: 493-498.

Mosello, R. \& B.M. Wathne. 1997. Surface water. Chemical analysis of major ions and nutrients. Analytical quality control. In: Wathne, B.M (Ed.), MOLAR. Measuring and modelling the dynamic response of remote mountain lake ecosystem to environmental change: A programme of Mountain lake Research. MOLAR Project Manual. NIVA Report 0-96061: 24-45.

Mosello, R., M. Bianchi, M.C. Brizzio, H. Geiss, W. Leyendecker, A. Marchetto, G. Serrini, G. Serrini Lanza, G.A Tartari \& H. Muntau. 1998a. AQUACON-MedBas Sub- project No. 6. Acid rain analysis. Intercomparison 1/97. Joint Res. Centre European Commission, Rep. EUR 18135 EN: $65 \mathrm{pp}$

Mosello, R., M. Bianchi, H. Geiss, A. Marchetto, G. Serrini, G. Serrini Lanza, G.A. Tartari \& H. Muntau. 1998b. AQUACON-MedBas Subproject $N^{\circ} 5$. Freshwater analysis. Intercomparison 1/97. Joint Res. Centre European Commission, Rep. EUR 18075 EN: 66 pp.

Patrick, S., R.W. Battarbee, B. Wathne \& R. Psenner. 1998. Measuring and modelling the dynamic response of remote mountain lake ecosystems to environmental change: an introduction to MOLAR project. Proc. of the HeadWater '98 Conference, Meran/Merano, Italy, April 1998, IAHS Publ. 248: 403-410.

Rihm, B. 1994. Critical loads of acidity for forest soils and Alpine lakes. Steady State Mass Balance Method. Federal Office of Environment, Forests and Landscape (FOEFL). Environmental Series 234: 68 pp.

Schuurkes, J.A.A.R. \& R. Mosello. 1988. The role of external ammonium inputs in freshwater acidification. Schweiz. Z. Hydrol., 50: 71-86.

Simona M., A. Barbieri, M. Veronesi, S. Malusardi \& V. Straskrabova. 1999. Seasonal dynamics of plankton in a mountain lake in the southern Alps (Laghetto Inferiore, Switzerland). J. Limnol., 58(2):169-178.

Stumm, W. \& J.J. Morgan. 1981. Aquatic chemistry. Wiley and Sons, New York: 780 pp.

Tartari, G.A. \& R. Mosello. 1997. Metodologie analitiche e controlli di qualità nel laboratorio chimico dell'Istituto Italiano di Idrobiologia. Documenta Ist. ital. Idrobiol., 60: $160 \mathrm{pp}$.

The MOLAR Water Chemistry Group. 1999. The MOLAR Project: atmospheric deposition and lake water chemistry. J. Limnol., 58(2): 88-106.

Van Breemen, N., C.T. Driscoll \& J. Mulder. 1984. Acid deposition and internal proton sources in acidification of soils and waters. Nature, 307: 599-604.

Vollenweider, R.A. 1975. Input-output Models With Special Reference to the Phosphorus Loading Concept in Limnology. Swiss Journal of Hydrology,73: 53-82.

Zobrist, J. \& J.I. Drever. 1990. Weathering processes in alpine watersheds sensitive to acidification. In: Johannessen M., R. Mosello \& H. Barth (Eds), Acidification processes in remote mountain lakes. Pallanza, 20-22 June 1989: 149161. 